\title{
Induction of somatic embryogenesis as an example of stress-related plant reactions
}

\author{
Maria Amely Zavattieri* \\ Laboratory of Plant Breeding and Biotechnology \\ Institute of Mediterranean Agricultural and Environmental Sciences \\ University of Évora \\ Évora, Portugal \\ E-mail: zavattieri@uevora.pt \\ António Miguel Frederico \\ EU Marie Curie Chair \\ Institute of Mediterranean Agricultural and Environmental Sciences \\ University of Évora \\ Évora, Portugal \\ Mónica Lima \\ Laboratory of Plant Breeding and Biotechnology \\ Institute of Mediterranean Agricultural and Environmental Sciences \\ University of Évora \\ Évora, Portugal \\ Rui Sabino \\ Institute of Mediterranean Agricultural and Environmental Sciences \\ University of Évora \\ Évora, Portugal

\section{Birgit Arnholdt-Schmitt} \\ EU Marie Curie Chair \\ Institute of Mediterranean Agricultural and Environmental Sciences \\ University of Évora \\ Évora, Portugal \\ Website: http://www.icam.uevora.pt
}

Financial support: Institute of Mediterranean Agricultural and Environmental Sciences (ICAAM), University of Évora, $7002-554$ Évora, Portugal.

Keywords: cell reprogramming, reactive oxygen species, somatic embryogenesis, stress.

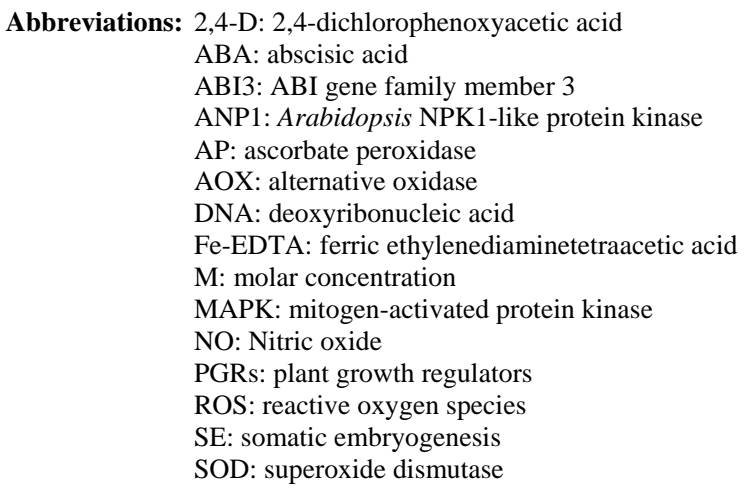

In this review, we address the role of stress as one of the principal causes for a cell or tissue to change its preexisting somatic program, reprogramming itself to express the embryogenic pathway. The focus of this paper is the effect of different stress conditions on the induction phase of plant somatic embryogenesis, as well as the development of embryogenic competence as a result of the applied stresses. We also present a variety of data that link plant somatic embryogenesis, DNA methylation and oxidative stress response.

*Corresponding author 
Asexual reproduction is fairly common in plants, allowing them to survive in their natural habitats completely independent of pollinating vectors. Two types of asexual reproduction are recognised, in both the offspring are typically genetically identical to their parent. First, vegetative reproduction is the asexual reproduction of an individual (genet), which developed originally from a zygote into physiologically independent units (ramets). Second, agamospermy or apomixis refers to the production of fertile seeds without sexual fusion of gametes (Traveset, 1999). At least 400 species in 40 families are encountered, including the Poaceae, Asteraceae, Rosaceae and Rutaceae. In addition to agamospermy, it is possible to induce somatic embryogenesis (SE) from in vitro cultured plant cells. According to Fehér (2005), this phenomenon demonstrates two important aspects of plant embryogenesis: namely (1) that the fertilization trigger can be substituted by endogenous mechanisms, and (2) that in higher plants other cell types, in addition to the fertilized egg cell, can maintain or regain the capability for embryogenic development. Fehér et al. (2003) considered this to be one of the most extreme examples of flexibility in plant development. SE may arise naturally from isolated somatic cells, as has been observed in Kalanchoe where somatic embryos form spontaneously on the edge of leaves, or in vitro after experimental induction. The latter requires the induction of embryogenic competence in cells which are not naturally embryogenic (Dodeman et al. 1997). SE induction is only possible if somatic plant cells regain their totipotency and acquire the competence necessary to respond to embryogenic signals and initiate embryogenesis (Pasternak et al. 2002).

The sequence of events for SE as a morphogenic phenomenon is frequently expressed as discrete phases or steps. These phases are characterized by distinct biochemical and molecular events (Suprasanna and Bapat, 2005). Thus, the more closely the pattern of somatic embryo gene expression matches that of zygotic embryos, the greater the chance of obtaining highly efficient regenerative systems (Merkle et al. 1995). There is, nevertheless, no international agreement amongst authors regarding the terminology for each step and the associated species. The first phase of SE is the induction stage in which differentiated somatic cells acquire embryogenic competence either directly (without a dedifferentiation step) or indirectly (by dedifferentiation and usually involving a callus phase). After the appropriate stimulus, this phase is followed by the expression or initiation of SE in which competent cells or proembryos start developing. Finally, during maturation, somatic embryos anticipate germination by desiccation and reserve accumulation (Jiménez, 2001). SE must therefore consist of replacement of the existing pattern of gene expression in the explant tissue for a new embryogenic gene expression program (Chugh and Khurana, 2002; Zeng et al. 2007). This is only possible if the cells are both competent and receive the appropriate inductor stimuli.
Embryogenic competence is expressed at the level of the single cell and these cells are capable of differentiating into embryos if they receive inducers of differentiation (Fehér, 2005). These competent embryogenic cells have specific characteristics, such as early activation of the division cycle, more alkalic vacuolar $\mathrm{pH}$, an altered auxin metabolism, and a non-functional chloroplast (Pasternak et al. 2002).

The signals inducing competence and triggering embryogenic development are not easy to separate. Cellular competence is associated with the dedifferentiation of somatic cells that allows them to respond to new developmental signals (Potters et al. 2007). Fehér (2005) described the morphological and physiological aspects that distinguish embryogenic from non-embryogenic cells.

Two categories of inductive conditions which allow differentiated cells to develop into competent dedifferentiated cells are now recognized, these are: plant growth regulators (PGRs) (internal and/or external cellular levels) and stress factors (osmotic shock, culture medium dehydration, water stress, heavy metal ions, alterations of culture medium $\mathrm{pH}$, heat or cool shock treatments, hypoxia, antibiotics, ultraviolet radiation, and mechanical or chemical treatments) (Yu et al. 2001; Ikeda-Iwai et al. 2003; Aoshima, 2005; Fehér, 2005; Patnaik et al. 2005; Karami et al. 2006; Begun et al. 2007; Potters et al. 2007; Lincy et al. 2009). There is ample evidence that the PGRs act as central signals to reprogram somatic cells towards embryogenic pathways (Pasternak et al. 2002; Fehér et al. 2003; Gaj, 2004; Fehér, 2005; Jiménez and Thomas, 2005; Thomas and Jiménez, 2005). Studies at the molecular level support the correlation of PGRs with the control of chromatin remodeling and gene expression during induction of SE (Dudits et al. 1995; Fehér, 2008), as well as their involvement throughout the SE process. Auxins are considered to be the most important PGRs that regulate SE induction. The endogenous content and the application of exogenous auxins are both determining factors during the induction phase (Thomas and Jiménez, 2005). For a couple of reasons, the internal hormone content appears to be an inadequate marker of embryogenic potential. First, the internal hormone levels are extremely variable in competent cells of different genotypes and species. Second, in the same experiment, very few differences were observed between competent and noncompetent genotypes. For these reasons, other factors must be involved in determining the competence of explants (Jiménez and Thomas, 2005).

Based on the wide variation of inducers, SE cannot be defined as a specific response to one or more exogenously applied PGRs. On the contrary, these observations indicate that stress plays a critical role as an embryogenic stimulus.

The aim of this review is to summarize research works related to the involvement of stress in the induction of plant $\mathrm{SE}$ and also to emphasize the diversity of the stressors that 
could be used to change the predetermined somatic programme and express the totipotency of the plant cells through SE. Numerous publications about the molecular mechanisms involved in the stress-induced signalling of SE are now emerging, of which just a few are cited here, this justify that the authors are preparing a second part to complete the information presented.

\section{STRESS AND SOMATIC EMBRYOGENESIS}

In recent years, considerable attention has been devoted to the way stress affects plants and how plants actually respond to stressful conditions. Kacperska (2004) defined stress as "potentially adverse environmental conditions (stressors) that affect plant growth and development and trigger a wide range of responses, from altered gene expression and modification in cellular metabolism to change in growth rate and crop yield". In an opinion paper recently published, Potters at al. (2007) explained that stress-induced morphogenic response in plant cells could be summarised as: inhibition of cell elongation, localized stimulation of cell division and alteration of the cell differentiation status. These general cell responses were found to be the same independently of the type of stress.

In vitro culture conditions represent an unusual combination of stress factors that plant cells encounter (e.g. oxidative stress as a result of wounding at excision of the explant tissue, PGRs, low or high salt concentration in solution, low or high light intensities). The stress associated with in vitro induction of SE may result in an overall stress response as expressed as chromatin reorganization. An extended chromatin reorganization is believed to cause an 'accidental' release of the embryogenic program, the latter normally being repressed by a chromatin-mediated gene silencing mechanism (Fehér, 2005). An increasing number of studies (Steward et al. 2002; Williams et al. 2003; Law and Suttle, 2005) demonstrate that release of the SE is unlikely to be 'accidental'. On the contrary, highly organized patterns of deoxyribonucleic acid (DNA) methylation/demethylation and histone acetylation/deacetylation have been observed during cellular dedifferentiation/differentiation stages. Direct evidence for changes of DNA methylation during SE is well documented (Santos and Fevereiro, 2002; Chakrabarty et al. 2003; Leljak-Levanic et al. 2004). However, the ability of in vitro cultures to generate embryos is limited to a group of cells or a discrete zone of embryogenic callus (Quiroz-Figueroa et al. 2006).

Pronounced changes in the cellular environment may generate stress effects, such as exposing wounded cells or tissues to sub-optimal nutrient or PGRs. Response to these applied stresses depends on the level of stress and the physiological state of the cells. High stress may cause the cells to die if they are unable to tolerate this stress level. Other effects of stress are associated with adaptation mechanisms, such as cell reprogramming and cell modification in the physiological and metabolic pathways
(Pasternak et al. 2002). Stress not only promotes dedifferentiation but can also induce somatic embryo formation.

In carrot (Daucus carota), a model plant for SE, stress treatment on the PGR-free medium induces SE in the presence of different chemicals such as $0.7 \mathrm{M}$ sucrose, 0.3 $\mathrm{M} \mathrm{NaCl}$ or $0.6 \mathrm{mM} \mathrm{CdCl}$ (Kamada, et al. 1989; Kiyosue et al. 1989; Harada et al. 1990; Kiyosue et al. 1990; Kamada et al. 1993).

A stressful cool pre-treatment at $2^{\circ} \mathrm{C}$ for 3 days on activated charcoal and the presence of minimal concentrations of $\mathrm{Ca}^{2+}$ was necessary to induce white mucilaginous embryogenic tissue derived from shoots apices in mature Pinus patula (Malabadi and van Staden, 2006). More recently Lincy et al. (2009) found that a period of stress caused by dehydration was favourable to induce SE from callus cultures of ginger (Zingiber officinale). Direct SE was observed from the aerial stem and leaf base explants of ginger with the use of thidiazuron alone or in combination with indole-3-butyric acid (IBA), yet embryogenic calli were obtained only in cultures not subcultured for 40-60 days.

In Arabidopsis, a member of the mustard family, stress was the most important factor controlling induction of somatic embryos. Osmotic, heavy metal ions and dehydration stresses induced formation of somatic embryos (Ikeda-Iwai et al. 2003). These authors concluded that the duration of stress treatment was the most important factor and that the optimum stress treatment differed among different stressors. At least five interactive critical factors were recognised, including tissue origin, the developmental phase of the source plant, origin of the stress, stress due to chemical concentration and duration of stress treatment.

Akula et al. (2000) investigated the role of various osmotic compounds as well as abscisic acid (ABA) in the induction phase of SE in tea (Camellia sinensis). Addition of betaine to the induction medium significantly enhanced the rapid formation of somatic embryos, without callusing, of mature fresh seeds of tea within two weeks of culture initiation. The induction response was further enhanced when ABA (7.5 $\mathrm{mgl}^{-1}$ ) was co-supplemented with betaine in the induction medium. The rate of induction of SE increased linearly with external betaine concentration, thus confirming that the induction response by betaine was manifested as an osmotic rather than a nutrient factor. Betaine is known to serve as a nitrogen source when it is supplied in low concentrations, and to act as an osmolyte at higher concentrations. Present results, therefore, support previous studies which indicate that mild osmotic stress is responsible for driving regeneration.

Fehér et al. (2003) suggested that 2,4dichlorophenoxyacetic acid (2,4-D) functions as a stress chemical as well as an auxin. They pointed out that "if we could answer the question why this synthetic auxin is so 
efficient in this respect, we may get closer to understanding the processes underlying the induction phase of SE". In carrot SE 2,4-D is required for the initiation of a program that can proceed further on its own, while the removal of 2,4-D from the induction medium may be important to control the cellular polarity, which is one of the first cytological event in the initiation phase. For this reason 2,4D not only mimics auxins (concentration-dependent mode of action) (Raghavan et al. 2006) but also, may preferentially induce stress responses in plant cells similar to other stress conditions (Grossmann, 2000).

Early stages of SE are characterized by the induction of many stress-related genes (Davletova, 2001) leading to the hypothesis that SE is an extreme stress response of cultured plant cells (Dudits et al. 1995).

ABA is believed to act as a "stress hormone" in plants, and in some experimental systems has been reported to induce SE (Charriére et al. 1999; Nishiwaki et al. 2000; Senger et al. 2001). Induction of carrot SE by ABA and stress treatments show that the endogenous levels of ABA increased in response to stress treatments, up to 67.5 times higher than non-embryogenic cells that had lost the ability to form somatic embryos (Kiyosue et al. 1992; Kikuchi et al. 2006). The hypothesis that stress-induced accumulation of endogenous ABA is involved in the induction of carrot SE, as well as the significance of ABA when somatic cells of carrot acquire the embryogenic competence was proved on the basis of C-ABI3 expression. ABI gene family member 3 (ABI3) is a gene involved in seed-specific signal transduction of ABA and expressed also in embryogenic tissue with positive correlation with embryogenic cell proteins (ECPs). The acquisition of embryogenic competence in the stress-induced system of carrot increased linearly during stress-treatment periods from 1 to 4 weeks. Kikuchi et al. (2006) suggested that there is a clear separation of two phases in the stress induction system: namely, acquisition of embryogenic competence and formation of the somatic embryos. In contrast, the endogenous level of ABA reached a peak within 1 week of the stress treatment, after which it gradually decreased through the rest of the stress treatment. The expression of C-ABI3 in explants exposed to stress for 4 days indicated that ABA signal transduction might be active during the early stages of stress treatment. They concluded that somatic cells acquire embryogenic competence during stress. The stresses and the appearance of ABA were both essential for the acquisition of the embryogenic competence. They also indicated that no PGR application was needed in a stress-induction system for SE.

\section{Oxidative stress}

An increasing number of publications link reactive oxygen species (ROS) and SE. Oxidative stress-inducing compounds increase the cell endogenous auxin levels and promote dedifferentiation (Pasternak et al. 2002; CorreaAragunde et al. 2006). Kairong et al. (2002) suggested that plant SE is a special cell differentiation process and established a link or "partial overlapping" of ROS and cell differentiation. Working with the wolfberry shrub Lycium barbatum, Kairong et al. (2002) established a correlation between hydrogen peroxide $\left(\mathrm{H}_{2} \mathrm{O}_{2}\right)$ treatment and the induction effect for SE. Their results also showed that the superoxide dismutase (SOD) activity gradually increased in the early days of differentiation culture, and then gradually decreased with further division and development of multicellular embryos. $\mathrm{H}_{2} \mathrm{O}_{2}$, generated by various environmental and developmental stimuli, can act as a signalling molecule that regulates plant development, stress adaptation, and programmed cell death (PCD) (Apel and Hirt, 2004). Thus $\mathrm{H}_{2} \mathrm{O}_{2}$ acts as a cellular second 'messenger' capable of inducing gene expression and protein synthesis, and promoting SE. Another experimental result showed that $\mathrm{H}_{2} \mathrm{O}_{2}$ could regulate gene expression of the cell oxidative response at transcription level, thus regulating antioxidant enzymes as SO. In an extended review of the signal transduction during oxidative stress, Vranová et al. (2002) inferred that while cell-cycle progression is under negative control of ROS, $\mathrm{H}_{2} \mathrm{O}_{2}$ stimulates SE. According these authors, the role of ROS in plant growth and development requires further investigation. $\mathrm{H}_{2} \mathrm{O}_{2}$ is a well-known product of oxidative stress and plays multiple roles in plant physiology. $\mathrm{H}_{2} \mathrm{O}_{2}$ belongs to the class of ROS produced in photosynthetic tissues, mitochondria, and also in the cytosol under certain stress conditions, such as cold, drought, salt stress or pathogen attack. Kovtun et al. (2000) showed that $\mathrm{H}_{2} \mathrm{O}_{2}$ is a potent activator of mitogen-activated protein kinases (MAPKs) in Arabidopsis leaf cells. They found that $\mathrm{H}_{2} \mathrm{O}_{2}$ can activate a specific kinase, Arabidopsis NPK1-like protein kinase (ANP1), which initiates a phosphorylation cascade involving two stress MAPKs, AtMPK3 and AtMPK6. Constitutively active ANP1 mimics the $\mathrm{H}_{2} \mathrm{O}_{2}$ effect and initiates the mitogen-activated protein kinase (MAPK) cascade that induces specific stress-responsive genes, but it blocks the action of auxin, a plant mitogen and growth hormone. These observations provide a molecular link between oxidative stress and auxin signal transduction.

Ötvös et al. (2005), working with alfalfa cell culture, also showed that $\mathrm{H}_{2} \mathrm{O}_{2}$ and Nitric oxide (NO) have a promoting effect on SE. NO stimulates the activation of cell division and embryogenic cell formation in leaf-protoplast cells of alfalfa, in the presence of auxins. So cells regain the ability to divide during dedifferentiation, and then to redifferentiate into embryogenic cells. However, they did not find that NO was required for the progression of the embryogenic pathway. Some aspects of the downstream events of the putative NO-dependent signalling cascade, leading to mitotic activation of auxin, needs to be investigated.

Pasternak et al. (2002) attempted to provide more evidence that stress reactions were involved in the process of SE. In their experiment with alfalfa leaf protoplast-derived cells, increased $\mathrm{Fe}$ as ferric ethylenediaminetetraacetic acid (Fe- 
EDTA) $\left(1 \times 10^{-3} \mathrm{M}\right)$ resulted in the development of the same cell morphology as in the case of the medium with 2,4-D $(10 \mu \mathrm{M})$. Fe-EDTA treatment increased the activity of ascorbate peroxidase (AP), a scavenger of $\mathrm{H}_{2} \mathrm{O}_{2}$, indicating an oxidative stress response in the cells. Similar results were derived from other oxidative stress-inducing agents such as copper, menadione, paraquat or alloxan; applied at non-lethal concentrations these agents appeared to promote both, cell division and embryogenic cell formation under non-embryogenic conditions (Pasternak et al. 2002; Ötvös et al. 2005). They postulated that parallel activation of auxin and stress signalling may be a key event in cellular adaptation, reprogramming of gene expression patterns, cellular metabolism and physiology, resulting in totipotency and embryogenic competence acquisition of plant somatic cells.

The hypothesis that SE is a specific form of stress response related to an adaptation process is supported by experiments which show that a heat-shock system is involved in the developmental reprogramming. Furthermore, some common elements of auxin and heatshock response are predicted from molecular studies (Pitto et al. 1983). Recent evidence supports the idea that stress response, oxidative stress and SE may be related. For example, Ganesan and Jayabalan (2004) showed that addition of haemoglobin to the culture medium increased SE efficiency in cotton, especially in cultures treated with $400 \mathrm{mgl}^{-1}$ of haemoglobin, by increasing the oxygen level and inducing stress in the growing tissues. Increased levels of antioxidant enzyme activity, such as SOD and peroxidase, indicate that excess oxygen uptake and stressed condition of plant tissue resulted from haemoglobin supplementation. This increased oxygen uptake and haemoglobin-mediated stress apparently accelerated SE in cotton.

MAPK cascades may link auxin signalling to oxidative stress responses and cell cycle regulation (Hirt, 2000; Neil et al. 2002). Activation of MAPKhas also been involved in stress-related ABA signalling (Knetsch et al. 1996). It thus appears likely that the primary function of downstream regulatory proteins, such as MAPKs, is to bridge the gap in embryogenesis induction of different types of cells.

Stress factors have been observed to trigger reprogramming of microspores into embryos (Maraschin et al. 2005). The authors postulated that many stress factors may be responsible for reprogramming microspores into embryos, suggesting that initiation of androgenesis might be induced by converging signalling pathways. Although different stress signals may trigger the same downstream pathway, analogous situations may also be found during the induction of SE.

\section{DNA methylation}

In 1994, Phillips et al. (1994) reviewed the genetic instability related to tissue culture, suggesting that the changes observed at the genetic level were most likely due to a stress-response mechanism. The relevant mechanism may be described as a programmed loss of cellular control. The most commonly observed plant tissue culture-imposed changes include: chromosome rearrangements, DNA methylation, and mutations. These authors associated 2,4-D and higher levels of other auxins, such as 1naphthaleneacetic acid (NAA) and Indole-3-acetic acid (IAA), with increases in DNA methylation throught increased levels of methylated cytosines. Leljak-Levanic et al. (2004), working with pumpkin embryogenic lines that were initiated on wounded zygotic embryos in a 2,4-D medium or in an auxin-free medium supplemented with $\mathrm{NH}_{4} \mathrm{Cl}(1 \mathrm{mM})$, found that high rates of DNA methylation correlated with early embryo development, and that the rate decreased during embryo maturation in an auxin-free medium. They suggested that the presence of 2,4-D as well as a low concentration of $\mathrm{NH}_{4} \mathrm{Cl}$ (the sole source of nitrogen in the PGR-free Murashige and Skoog (MS) medium) used in the culture system, might cause stress in the embryogenic culture and also that $\mathrm{SE}$ could be induced by stressful conditions through methylation changes. High levels of DNA methylation and early embryo development were not dependent exclusively on the presence or absence of exogenous auxin. However, the changes in chromatin structure were largely due to stresses caused by the in vitro conditions, and related especially to the PGRs. Furthermore, it is widely accepted that nitrogen supplied in the form of $\mathrm{NH}_{4}{ }^{+}$is harmful to many plant species (Von Wiren et al. 2000). It has also been suggested that the embryogenic effect of 2,4-D probably derives from its methylating action on the nuclear DNA (De Klerk et al. 1997). In fact, large amounts of 2,4-D are known to increase DNA methylation levels in carrot cultures (Kaeppler et al. 2000). Sharma et al. (2007) believe that DNA methylation is an indispensable process for initiating SE, although it also has the undesirable effect of inducing somaclonal variation, which can persist in regenerated plants and be partly transmitted to their progeny.

According to Dudits et al. (1995), during the process of cell dedifferentiation - callus formation and differentiation to somatic embryos, the nuclear DNA may undergo quantitative variations generated by amplification, underreplication, or elimination of specific sequences. In a study with soybean SE, Thibaud-Nissen (2003), immature cotyledons were placed on high levels of the auxin 2,4-D. Somatic embryos developed from the adaxial side of the cotyledon, whereas the abaxial side evolved into a callus. Using a 9,280-cDNA clone array, they compared by steadystate RNA the adaxial side (somatic embryos) from the abaxial (callus formation), at five time points over the course of the 4 weeks. The genes found were grouped according to the similarity of their expression profiles. Their results indicate that the appearance of somatic embryos is preceded by dedifferentiation of the cotyledon during the first 2 weeks on auxin. The changes in mRNA abundance of genes characteristic of oxidative stress and genes indicative of cell division were found in the adaxial 
side of the cotyledons suggest that the arrangement of the new cells into organized structures might depend on a genetically controlled balance between cell proliferation and cell death.

Although not all of the intermediates of the auxin response are known, it is established that 2,4-D and light are able to induce an oxidative burst in the target tissue by generating ROS (Pfeiffer and Höftberger, 2001). The drastic changes in the cellular environment of the in vitro culture, induced by a 'stressor' in the culture medium or in the physical environment of the culture, are responsible for reprogramming of gene expression. In this context, the stress not only promotes dedifferentiation, but also induces somatic embryo formation (Fehér et al. 2003). If MAPK phosphorylation cascades link oxidative stress responses to auxin signalling and cell cycle regulation, then other types of stress-oxidative-responses may also be associated with cell reprogramming. Stress-inducible cell signalling compounds, such as $\mathrm{H}_{2} \mathrm{O}_{2}$ and $\mathrm{NO}$, are known to induce AOX1 genes (Vranová et al. 2002) and SE (Kairong et al. 1999; Kairong et al. 2002). Alternative oxidase lowers mitochondria ROS formation in plants cells. Thus the existence of a direct correlation between alternative oxidase (AOX) gene expression, stress responses and cellular reprogramming through the embryogenic pathway must be considered (Arnholdt-Schmitt et al. 2006).

\section{CONCLUDING REMARKS}

Although fragmentary and difficult to unify, the experimental results covered in this review highlight some suggestions to explore the function of stress as a required condition for the induction of plant SE. Based on the examples presented, SE could be considered as a cell response to exogenously applied stressors. The review also links the embryogenic pathway induced by stress with oxidative burst and changes in cell metabolism, and suggests that the new embryogenic program could be facilitated through the establishment of less repressed chromatin structure. Nevertheless, further work will be required in specific areas as genomics, proteomics and metabolomics to clarify the global role of stress in the cellular mechanisms conducting to SE induction in plants.

\section{ACKNOWLEDGMENTS}

We like to thank especially Dr. Krystyna Klimaszewska (Canadian Forest Service, Laurentian Forestry Centre, Quebec) for encouragement to publish this review and also for her critical reading and suggestions.

Sincere appreciation is extended to Dr. Anthony Tankard (Tankard Entrepise, Calgary, Alberta, Canada) for his invaluable help in editing the present review and to Professor Dr. Miguel Pedro Guerra (Universidade Federal de Santa Catarina, Brazil) for critical reading of the manuscript.

\section{REFERENCES}

AKULA, Anisha; AKULA, Chakradhar and BATESON, Marion F. Betaine a novel candidate for rapid induction of somatic embryogenesis in tea (Camellia sinensis (L.) O. Kuntze). Plant Growth Regulation, March 2000, vol. 30, no. 3, p. 241-246.

AOSHIMA, Yoichi. Efficient embryogenesis in the callus of tea (Camellia sinensis) enhanced by the osmotic stress or antibiotics treatment. Plant Biotechnology, January 2005, vol. 22, no. 4, p. 277-280.

APEL, Klaus and HIRT, Heribert. Reactive oxygen species: metabolism, oxidative stress, and signal transduction. Annual Review of Plant Biology, June 2004, vol. 55, p. 373399.

ARNHOLDT-SCHMITT, Birgit; COSTA, José H. and FERNANDES DE MELO, Dirce. AOX - a functional marker for efficient cell reprogramming under stress? Trends in Plant Science, June 2006, vol. 11, no. 6, p. 281287.

BEGUN, Yasmin; ROY, Sumana; BANDYOPADHYAY, Sanmoy; BANDYOPADHYAY, Subhendu; DASGUPTA, Uma; CHAKRABORTY, Anindita and RAYCHAUDHURI, Sarmistha Sen. Radiation induced alterations in Vigna radiata during in vitro somatic embryogenesis. International Journal of Radiation Biology, December 2007, vol. 84, no. 2, p. 165-175.

CHAKRABARTY, D.; YU, K.W. and PAEK, K.-Y. Detection of DNA methylation changes during somatic embryogenesis of Siberian ginseng (Eleuterococcus senticosus). Plant Science, July 2003, vol. 165, no. 1, p. 6168.

CHARRIÉRE, François; SOTTA, Bruno; MIGINIAC, Émile and HAHNE, Günter. Induction of adventitious shoots or somatic embryos on in vitro cultured zygotic embryos of Helianthus annuus: Variation of endogenous hormone levels. Plant Physiology and Biochemistry, October 1999, vol. 37 no. 10, p. 751-757.

CHUGH, Archana and KHURANA, Paramjit. Gene expression during somatic embryogenesis - recent advances. Current Science, September 2002, vol. 83, no. 6, p. 715-739.

CORREA-ARAGUNDE, Natalia; GRAZIANO, Magdalena; CHEVALIER, Christian and LAMATTINA, Lorenzo. Nitric oxide modulates the expression of cell cycle regulatory genes during lateral root formation in tomato. Journal of Experimental Botany, February 2006, vol. 57, no. 3, p. 581-588.

DAVLETOVA, Sholpan; MÉSZÁROS, Tamás; MISKOLCZI, Pál; OBERSCHALL, Attila; TÖRÖK, Kataline; MAGYAR, Zoltán; DUDITS, Dénes and DEÁK, 
Mária. Auxin and heat shock activation of a novel member of the calmodulin like domain protein kinase gene family in cultured alfalfa cells. Journal of Experimental Botany, February 2001, vol. 52, no. 355, p. 215-221.

DE KLERK, G.-J.; ARNHOLDT-SCHMITT, B.; LIEBEREI, R. and NEUMANN, K.H. Regeneration of roots, shoots and embryos: physiological, biochemical and molecular aspects. Biologia Plantarum, January 1997, vol. 39, no. 1, p. 53-66.

DODEMAN, Valrie Laurence; DUCREUX, Georges and KREIS, Martin. Zygotic embryogenesis versus somatic embryogenesis. Journal of Experimental Botany, August 1997, vol. 48, no. 7, p. 1493-1509.

DUDITS, Dénes; GYÖRGYEY, János; BÖGRE, László and BAKO, László. Molecular biology of somatic embryogenesis. In: THORPE, Trevor A. ed. In vitro Embryogenesis in Plants. Kluwer Academic Publishers, Dordrecht, The Netherlands, 1995, p. 267-308.

FEHÉR, Attila; PASTERNAK, Taras P. and DUDITS, Dénes. Transition of somatic plant cells to an embryogenic state. Plant Cell, Tissue and Organ Culture, September 2003, vol. 74, no. 3, p. 201-228.

FEHÉR, Attila. Why somatic plant cells start to form embryos? In: Mujid, Abdul and Samaj, Josef. eds. Somatic Embryogenesis. Plant Cell Monographs, Springer; Berlin/Heidelberg, 2005, vol. 2, p. 85-101.

FEHÉR, Attila. The initiation phase of somatic embryogenesis: what we know and what we don't. Acta Biologica Szegediensis, 2008, vol. 52, no. 1, p. 53-56.

GAJ, Malgorzata D. Factors influencing somatic embryogenesis induction and plant regeneration with particular reference to Arabidopsis thaliana (L.) Heynh. Plant Growth Regulation, May 2004, vol. 43, no. 1, p. 2747.

GANESAN, Markkandan and JAYABALAN, Narayanasamy. Evaluation of haemoglobin (erythrogen): for improved somatic embryogenesis and plant regeneration in cotton (Gossypium hirsutum L. cv. SVPR 2). Plant Cell Reports, October 2004, vol. 23, no. 4, p. 181-187.

GROSSMANN, Klaus. Mode of action of auxinic herbicides: a new ending to a long, drawn out story. Trends in Plant Science, December 2000, vol. 5, no. 12, p. 506508.

HARADA, H.; KIYOSUE, T.; KAMADA, H. and KOBAYASHI, T. Stress-induced carrot somatic embryogenesis and its application to synthetic seeds. In: SANGWAN, R.S. and SANGWANG-NORREEL, R.S. eds. The impact of Biotechnology in Agriculture. Kluwer Academic Publishers, The Neetherlands, 1990, p. 129-157.
HIRT, Heribert. Connecting oxidative stress, auxin, and cell cycle regulation through a plant mitogen-activated protein kinase pathway. Proceedings of the National Academy of Sciences of the United States of America, March 2000, vol. 97, no. 6, p. 2405-2407.

IKEDA-IWAI, Miho; UMEHARA, Mikihisa; SATOH, Shinobu and KAMADA, Hiroshi. Stress-induced somatic embryogenesis in vegetative tissues of Arabidopsis thaliana. The Plant Journal, April 2003, vol. 34, no. 1, p. 107-114.

JIMÉNEZ, Victor M. Regulation of in vitro somatic embryogenesis with emphasis on the role of endogenous hormones. Revista Brasileira de Fisiologia Vegetal, 2001, vol. 13, no. 2, p. 196-223.

JIMÉNEZ, Victor M. and THOMAS, C. Participation of plant hormones in determination and progression of somatic embryogenesis. In: MUJID, A. and SAMAJ, J. eds. Somatic Embryogenesis: Plant Cell Monographs. Springer; Berlin/Heidelberg, 2005, vol. 2, p. 103-118.

KACPERSKA, Alina. Sensor types in signal transduction pathways in plant cells responding to abiotic stressors: do they depend on stress intensity? Physiologia Plantarum, January 2004, vol. 122, no. 2, p. 159-168.

KAEPPLER, S.M.; KAEPPLER, H.F. and RHEE, Y. Epigenetic aspects of somaclonal variation in plants. Plant Molecular Biology, June 2000, vol. 43, no. 2-3, p. 179-188.

KAIRONG, Cui; GENGSHENG, Xing; LIN, Qin; XINMIN, Liu and YAFU, Wang. The analysis of differential gene expression in early somatic embryogenesis on Lycium barbarum. Plant Cell, Tissue and Organ Culture, December 1999, vol. 59, no. 3, p. 169-174.

KAIRONG, Cui; JI, Li; GENGMEI, Xing; JIANLONG, Li; LIHONG, Wang and YAFU, Wand. Effect of hydrogen peroxide on synthesis of proteins during somatic embryogenesis in Lycium barbarum. Plant Cell, Tissue and Organ Culture, February 2002, vol. 68, no. 2, p. 187-193.

KAMADA, Hiroshi; KOBAYASHI, Katsunori; KIYOSUE, Tomohiro and HARADA, Hiroshi. Stress induced somatic embryogenesis in carrot and its application to synthetic seed production. In vitro Cellular and Developmental Biology - Plant, December 1989, vol. 25, no. 12, p. 11631166.

KAMADA, Hiroshi; ISHIKAWA, Keiko; SAGA, Hitoshi and HARADA, Hiroshi. Induction of somatic embryogenesis in carrot by osmotic stress. Plant Tissue Culture Letters, 1993, vol. 10, no. 1, p. 38-44.

KARAMI, Omid; DELJOU, Ali; ESNA-ASHARI, Mahmoud and OSTAD-AHMDI, Prisa. Effect of sucrose concentrations on somatic embryogenesis in carnation 
(Dianthus caryophyllus L.). Scientia Horticulturae, November 2006, vol. 110, no. 4, p. 340-344.

KIKUCHI, Akira; SANUKI, Nobuya; HIGASHI, Katsumi; KOSHIBA, Tomokazu and KAMADA, Hiroshi. Abscisic acid and stress treatment are essential for the acquisition of embryogenic competence by carrot somatic cells. Planta, 2006, vol. 223, no. 4, p. 637-645.

KIYOSUE, Tomohiro; KAMADA, Hiroshi and HARADA, Hiroshi. Induction of somatic embryogenesis by salt stress in carrot. Plant Tissue Culture Letters, August 1989, vol. 8, no. 3, p. 162-164.

KIYOSUE, Tomohiro; TAKANO, Koujiro; KAMADA, Hiroshi and HARADA, Hiroshi. Induction of somatic embryogenesis in carrot by heavy metal ions. Canadian Journal of Botany, 1990, vol. 68, no. 10, p. 2021-2033.

KIYOSUE, Tomohiro; YAMAGUCHI-SHINOZAKI, Kazuko; SHINOZAKI, Kazuo; HIGASHI, Katsumi; SATOH, Shinou; KAMADA, Hiroshi and HARADA, Hiroshi. Isolation and characterization of a cDNA that encodes ECP31, an embryogenic-cell protein from carrot. Plant Molecular Biology, May 1992, vol. 19, no. 2, p. 239249.

KNETSCH, Menno L.W; WANG, Mei; SNAARJAGALSKA, Ewa and HEIMOVAARA-DIJKSTRA, Sjoukje. Abscisic acid induces mitogen-activated protein kinase activation in barley aleurone protoplasts. Plant Cell, June 1996, vol. 8, no. 6, p. 1061-1067.

KOVTUN, Yelena; CHIU, Wan-Ling; TENA, Guillaume and SHEEN, Jen. Functional analysis of oxidative stressactivated mitogen-activated protein kinase cascade. Proceedings of the National Academy of Science of the United States of America, March 2000, vol. 97, no. 6, p. 2940-2945.

LAW, R. David and SUTTLE, Jeffry C. Chromatin remodelling in plant cell culture: patterns of DNA methylation and histone $\mathrm{H} 3 \mathrm{w}$ and $\mathrm{H} 4$ acetylation vary during growth of asynchronous potato cell suspensions. Plant Physiology and Biochemistry, June 2005, vol. 43, no. 6, p. 527-534.

LELJAK-LEVANIC, Dunja; BAUER, Natasha; MIHALJEVIC, Snjezana and JELASKA, Sibila. Changes in DNA methylation during somatic embryogenesis in Cucurbita pepo L. Plant Cell Reports, September 2004, vol. 23, no. 3, p. 120-127.

LINCY, Adinkudik K.; REMASHREE, Azhimala B. and SASIKUMAR, Bhaskaran. Indirect and direct somatic embryogenesis from aerial stem explants of ginger (Zingiber officinale Rosc.). Acta Botanica Croatica, April 2009, vol. 68, no. 1, p. 93-103.
MALABADI, Ravindra and VAN STADEN, Johannes. Cold-enhanced induction and maturation of somatic embryos from intact megagametophyte explants in Pinus patula is mediated by calcium. South African Journal of Botany, November 2006, vol. 72, no. 4, p. 613-618.

MARASCHIN, Simone de F.; PRIESTER, Wessel; SPAINK, Herman P. and WANG, Mei. Androgenic switch: an example of plant embryogenesis from the male gametophyte perspective. Journal of Experimental Botany, July 2005, vol. 56, no. 417, p. 1711-1726.

MERKLE, S.A.; PARROTT, W.A. and FLINN, B.S. Morphogenic aspects of somatic embryogenesis. In: THORPE, T.A. ed. In vitro Embryogenesis in Plants. Dordrecht; Kluwer Academic Publishers, 1995, p. 155-203.

NEIL, Steven J.; DESIKAN, Radhika; CLARKE, Andrew; HURST, Roger D. and HANCOCK, John T. Hydrogen peroxide and nitric oxide as signalling molecules in plants. Journal of Experimental Botany, May 2002, vol. 53, no. 372, p. 1237-1247.

NISHIWAKI, Morie; FUJINO, Kaien; KODA, Yasunori; MASUDA, Kiyoshi and KIKUTA, Yoshio. Somatic embryogenesis induced by the simple application of abscisic acid to carrot (Daucus carota L.) seedlings in culture. Planta, October 2000, vol. 211, no. 5, p. 756-759.

ÖTVÖS, Krisztina; PASTERNAK, Taras P.; MISKOLCZI, Pál; DOMOKI, Mónika; DORJGOTOV, Dulguun; SZÜCS, Attila; BOTTKA, Sandor; DUDITS, Dénes and FEHÉR, Attila. Nitric oxide is required for, and promotes auxinmediated activation of, cell division and embryogenic cell formation but does not influence cell cycle progression in alfalfa cell cultures. The Plant Journal, September 2005, vol. 43, no. 6, p. 849-860.

PASTERNAK, Taras P.; PRINSEN, Els; AYAYDIN, Ferhan; MISKOLCZI, Pái; POTTERS, Geert; ASARD, Han; VANONCKELEN, Harry A.; DUDITS, Dénes and FEHÉR, Attila. The role of auxin, $\mathrm{pH}$, and stress in the activation of embryogenic cell division in leaf protoplastderived cells of alfalfa. Plant Physiology, August 2002, vol. 129, no. 4, p. 1807-1819.

PATNAIK, D.; MAHALAKSHMI, A. and KHURANA, P. Effect of water stress and heavy metals on induction of somatic embryogenesis in wheat leaf base cultures. Indian Journal of Experimental Biology, August 2005, vol. 43, no. 8, p. 740-745.

PFEIFFER, Wolfgang and HÖFTBERGER, Margit. Oxidative burst in Chenopodium rubrum suspension cells: induction by auxin and osmotic changes. Physiologia Plantarum, February 2001, vol. 111, no. 2, p. 144-150.

PHILLIPS, Ronald L.; KAEPPLER, Shawn M. and OLHOFT, Paula. Genetic instability of plant tissue cultures: breakdown of normal controls. Proceedings of the 
National Academy of Sciences of the United States of America, June 1994, vol. 91, no. 12, p. 5222-5226.

PITTO, Letizia; LOSCHIAVO, Fiorella; GIULIANO, Giovanni and TERZI, Mario. Analysis of the heat shock protein pattern during somatic embryogenesis of carrot. Plant Molecular Biology, September 1983, vol. 2, no. 5, p. 231-237.

POTTERS, Geert; PASTERNAK, Taras; GUISEZ, Yves; PALME, Klaus J. and JANSEN, Marcel. Strees-induced morphogenic responses: growing out of trouble? Trends in Plant Science, March 2007, vol. 12, no. 3, p. 98-105.

QUIROZ-FIGUEROA, Francisco; ROJAS-HERRERA, Rafael; GALAZ-AVALOS, Rosa and LOYOLAVARGAS, Victor. Embryo production through somatic embryogenesis can be used to study cell differentiation in plants. Plant Cell Tissue and Organ Culture, August 2006, vol. 86, no. 3, p. 285-301.

RAGHAVAN, Chitra; ONG, Eng Kok; DALLING, Michael J. and STEVENSON, Trevor W. Regulation of genes associated with auxin, ethylene and ABA pathways by 2,4-dichlorophenoxyacetic acid in Arabidopsis. Functional and Integrative Genomics, January 2006, vol. 6, no. 1 , p. 60-70.

SANTOS, Dulce and FEVEREIRO, Pedro. Loss of DNA methylation affects somatic embryogenesis in Medicago truncatula. Plant Cell, Tissue and Organ Culture, August 2002, vol. 70, no. 2, p. 155-161.

SENGER, Sigrun; MOKC, Hans Peter; CONRAD, Udo and MANTEUFFEL, Renate. Immunomodulation of ABA function affects early events in somatic embryo development. Plant Cell Reports, February 2001, vol. 20, no. 2, p. 112-120.

SHARMA, Sanjeev Kumar; BRYAN, Glenn J.; WINFIELD, Mark O. and MILLAM, Steve. Stability of potato (Solanum tuberosum L.) plants regenerated via somatic embryos, axillary bud proliferated shoots, microtubers and true potato seeds: a comparative phenotypic, cytogenetic and molecular assessment. Planta, November 2007, vol. 226, no. 6, p. 1449-1458.

STEWARD, Nicolas; ITO, Mikako; YAMAGUCHI, Yube; KOIZUMU, Nozumo and SANO, Hiroshi. Periodic DNA methylation in maize nucleosomes and demethylation by environmental stress. Journal of Biological Chemistry, October 2002, vol. 277, no. 40, p. 37741-37746.

STONE, Sophia L.; HAUKSDOTTIR, Herborg; TROY, Andrew; HERSCHLEB, Jill; KRAFT, Edward and CALLIS, Judy. Functional analysis of the RING-type ubiquitin ligase family of Arabidopsis. Plant Physiology, January 2005, vol. 137, no. 1, p. 13-30.
SUPRASANNA, P. and BAPAT, V.A. Differential gene expression during somatic embryogenesis. In: MUJIB, A. and SAMAJ, J. eds. Somatic Embryogenesis, Plant Cell Monographs. Berlin; Springer-Verlag, 2005, vol. 2, p. 305320.

THIBAUD-NISSEN, Françoise; SHEALY, Robin T.; KHANNA, Anupama and VODKIN, Lila O. Clustering of microarray data reveals transcript patterns associated with somatic embryogenesis in soybean. Plant Physiology, May 2003, vol. 132, no. 1, p. 118-136.

THOMAS, Clément and JIMÉNEZ, Victor M. Mode of action of plant hormones and plant growth regulators during induction of somatic embryogenesis: molecular aspects. In: MUJIB, A. and SAMAJ, J. eds. Somatic Embryogenesis, Plant Cell Monographs. Berlin; SpringerVerlag, 2005, vol. 2, p. 157-175.

TRAVESET, Anna. Ecology of plant reproduction: Mating systems and pollination. In: PUGNAIRE, Francisco I. and VALLADARES, Fernando. eds. Handbook of Functional Plant Ecology. New York; Marcel Dekker, Inc., 1999, p. 545-588.

VON WIREN, Nicolaus; LAUTER, Frank-Roman; NINNEMANN, Olaf; GILLISEN, Bernd; WALCH-LIU, Pia; ENGELS, Christof; JOST, Wolfgang and FROMMER, Wolf B. Differential regulation of three functional ammoniun transporter genes by nitrogen in root hairs and by light in leaves of tomato. The Plant Journal, January 2000, vol. 21, no. 2, p. 167-175.

VRANOVÁ, Eva; INZÉ, Dirk and VAN-BREUSEGEN, Frank. Signal transduction during oxidative stress. Journal of Experimental Botany, May 2002, vol. 53, no. 372, p. 1227-1236.

WILLIAMS, Leor; ZHAO, Jing; MOROZAVA, Nadya; LI, Yan; AVIVI, Yigal and GRAFI, Gideon. Chromatin reorganization accompanying cellular differentiation is associated with modifications of histone H3, redistribution of HP1, and activation of E2F-target genes. Developmental Dynamics, September 2003, vol. 228, no. 1, p. 113-120.

YU, Tsong-Ann; YEH, Shyi-Dong and YANG, Jiu-Sherng. Effects of carbenicillin and cefotaxime on callus growth and somatic embryogenesis from adventitious roots of papaya. Botanical Bulletin of Academia Sinica, October 2001, vol. 42, no. 4, p. 281-286.

ZENG, Fanchang; ZHANG, Xianglong; CHENG, Lei; HU, Lisong; ZHU, Longfu; CAO, Jinglin and GUO, Xiaoping. A draft gene regulatory network for cellular totipotency reprogramming during plant somatic embryogenesis. Genomics, September 2007, vol. 90, no. 5, p. 620-628. 